\title{
The Effect Of Sustainability Reporting Disclosure Based On Global Reporting Initiative (GRI) G4 On Company Performance (A Study On Companies Listed In Indonesia Stock Exchange)
}

\author{
EINDE EVANA* \\ Universitas Lampung
}

\begin{abstract}
This research aims to analyze the effect of sustainability report disclosures which are variables of economic dimension, environment dimension and social dimension variables on company performance (Tobin's $Q$ ). The index used as a guideline sustainability report disclosure in this research is based on the Global Reporting Initiative (GRI) G4. The population in this research is the entire companies listed in Indonesia Stock Exchange in 2014-2015. The companies as the sample are based on the purposive sampling method chosen by some specific criteria. Type of data used in this research is secondary data. Data analysis uses multiple linear regression method using SPSS 22 as an analytical tool. The result of this research shows that the variable of economic dimension has a positive effect on company performance. On the other hand, variables of environment dimension and social dimension do not affect the company performance.
\end{abstract}

Keywords: Economic Dimension, Environment Dimension, Social Dimension, Company Performance, Tobin's $Q$

Intisari: Penelitian ini bertujuan untuk menganalisis pengaruh pengungkapan laporan keberlanjutan yang merupakan variabel dimensi ekonomi, dimensi lingkungan dan variabel dimensi sosial terhadap kinerja perusahaan (Tobin's Q). Indeks yang digunakan sebagai pengungkapan laporan keberlanjutan panduan dalam penelitian ini didasarkan pada Global Reporting Initiative (GRI) G4. Populasi dalam penelitian ini adalah seluruh perusahaan yang terdaftar di Bursa Efek Indonesia pada tahun 2014-2015. Perusahaan sebagai sampel didasarkan pada metode purposive sampling yang dipilih oleh beberapa kriteria tertentu. Jenis data yang digunakan dalam penelitian ini adalah data sekunder. Analisis data menggunakan metode regresi linier berganda menggunakan SPSS 22 sebagai alat analisis. Hasil penelitian menunjukkan bahwa variabel dimensi ekonomi berpengaruh positif terhadap kinerja perusahaan. Di sisi lain, variabel dimensi lingkungan dan dimensi sosial tidak berpengaruh pada kinerja perusahaan.

* Corresponding author: eindeevana@yahoo.co.id 
Kata kunci: Dimensi Ekonomi, Dimensi Lingkungan, Dimensi Sosial, Kinerja Perusahaan, $Q$ Tobin

\section{Introduction}

According to GRI (2013), a sustainability report is a sustainable report issued by a company or an organization on economic, environmental and social effects caused by daily activities. Sustainability report can help an organization to measure and understand their economic, environmental and social performances and then, to determine the goal as well as managing changes more effectively. In Indonesia, publicity of sustainability report has been a trend, one of them is because the existence of annual reward giving on sustainability report initiated by the institution of National Center for Sustainability Reporting (NCSR). Moreover, the strengthening stakeholders' demand encourages the company to give information that is transparent, accountable and the practice of good corporate governance (TarigandanSemuel, 2014)

The reward is giving on the sustainability report also occurs in developing countries such as Malaysia. Nor et al. (2016) stated that Malaysia International Chamber of Commerce and Industry (MICC) gives environment reward to organizations that have an awareness of environment because they have shown their concern toward the environment as a reward that will increase the reputation of the company.

Based on Figure 1 graph, the number of companies registering as ISRA members in 2008-2015, almost every year is increasing. Simbolon and Sueb (2016) explained that the phenomenon is occurring in Indonesia recently is the number of companies that disclose sustainability report is increasing each year, that was initiated only one company in 2005, then, increased up to sixty companies in 2014, whereas the sustainability report in Indonesia is still voluntary. It gives the understanding that companies have had more concerns related to sustainability in economic, environmental and social 
Figure1

The Trend of Total Participants of Indonesian Sustainability Report Award (ISRA) in 2008-2015

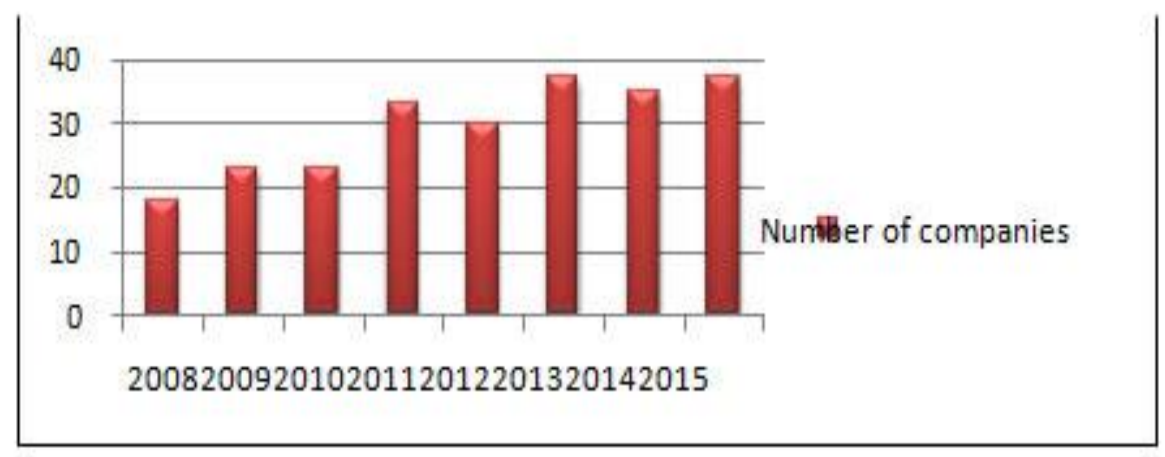

Source: NCSR

The study done by Safitri (2015) gave the result that the sustainability report of economic, environment and social dimension positively affect market performance. It happens if market actors see that sustainability report publication as the referrer to the increase of company capital, then, it will increase the market performance. Other study done by Eduardus and Juniarti (2016) gave the result that sustainability reporting and company financial performance that is proxied with Tobin's Q positively affect one to another. However, this study contradicts with the study was done by Muallifin and Priyadi (2016) giving the result that sustainability report does not affect Tobin's Q with a negative direction.

This study aims to investigate whether sustainability report disclosure of economic, environmental and social dimensions affects company performance that is proxied with Tobin's Q. This study uses the guidelines of Global Reporting Initiative (GRI) G4 as the foundation in measuring sustainability report by using 91 items of disclosures from all sustainability report disclosures. 


\section{Theoretical Framework and Hypothesis Development}

\subsection{Stakeholders Theory}

Stakeholder theory explains that a company must be able to manage and maintain its relationships with stakeholders. Freeman (1984) explained that the primary duty in the business process is managing and integrating the relation and the interests of shareholders, employees, customers, suppliers, community and other groups with the way that guarantees the long-term success of the company. The primary interest of stakeholder must be integrated into the primary goal of company, and the relation of stakeholder must be managed coherently and strategically. Tarigan and Semuel (2014) explained that one strategy to maintain the relationship with the stakeholders of a company is by disclosing sustainability report including economic, social and environmental aspects.

\subsection{Legitimacy Theory}

Laan (2009) revealed that the legitimacy theory argues that organizations will continuously search to ensure that they operate with limitations and norms of each society. Deegan (2004) in Tarigan and Semuel (2014) argued that companies try to ensure that external parties accept their activities (companies) as something legitimate. Activity report of the company's social and environmental responsibility that is expressed in a sustainability report can be used by the company to prove that the company has implemented social responsibility. It is meant so that the existence and activity of a company can be accepted by society.

\subsection{Sustainability Report}

According to Elkington (1997), sustainability report means a report that contains not only financial performance information but also non-financial information consisting of information of social and environmental activities that enable the company to be able to grow sustainably (sustainable performance). Meanwhile, according to the Global Report Initiative G4 in 2013, a sustainability report is a sustainable report issued by a company or an organization about economic, 420 
environmental and social effects caused by daily activities. A sustainability report is the form of a sustainable report developed by the Global Reporting Initiative. GRI established because the urgency of transparency of company business activities both economic, environmental and social so that the guidelines are needed to make sustainability report for the company in various sizes and business sectors in the entire world. The aims among others are to increase harmonization of the company toward stakeholder, both shareholder, management, employee or labor, government, nongovernmental organization, and society, to help the investor to have analysis entirely both technical and fundamental in investment decision making and others (Maharani, 2014).

\subsection{Company Performance}

Company performance consists of financial performance and market performance (Wibowo and Faradiza, 2014). Financial performance is used by management as a guideline to manage resources trusted to the management. Financial performance reflects the fundamental performance of the company that will be measured using data from the financial report (Simbolon and Sueb, 2016).

Figure2

Framework of Study

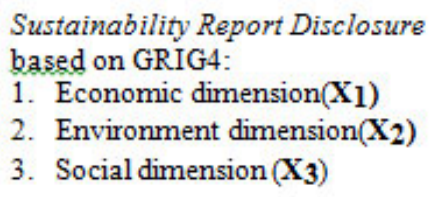

2. Environment dimension $\left(\mathbf{X}_{2}\right)$

3. Social dimension $\left(\mathbf{X}_{\mathbf{3}}\right)$

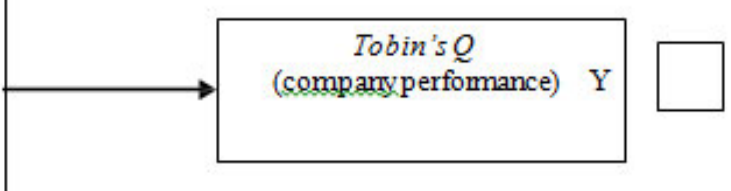

Market performance is an indicator used by internal and external parties of company to be able to measure how big, advanced and growing of a company and the one that can give the best information is the ratio of Tobin's Q (WibowoandFaradiza, 2014)., Tobin's Q is performance measurement that compares two evaluations of similar assets. Tobin's $\mathrm{Q}$ is a ratio of a company's asset market value measured by the market value of total outstanding shares and debt toward the replacement cost of company assets (Fiakas, 2005). Tobin's Q does not only give an illustration to 
fundamentals, but also to what extent the market values the company from various aspects that are viewed by external parties including investors (Wibowo and Faradiza, 2014).

\subsection{The Effect of Sustainability Report Disclosure of Economic Dimension on Company}

\section{Performance}

Economic dimension shows the effect of company operation on economic condition for its stakeholder. The information listed in the sustainability report of economic dimension (EC) can convince the potential of capital resources that are a competitive and low level of risk to the stakeholder (Tarigan and Semuel, 2014). Stakeholder, in this case, is an investor who needs transparent information related to the economic performance of a company as the consideration in the investment decision.

The studies done by Safitri (2015) as well as Fatchan and Trisnawati (2016) showed that sustainability report disclosure of economic performance has a positive and significant effect on the value of Tobin's $Q$. Tobin's $Q$ illustrates the market value of a company that reflects the future profit of the company (Wibowo and Faradiza,2014). Therefore, with high market value, the performance of the company will be valued good in the eye of the investor. Based on the above explanation, the hypothesis of this study is:

H1. Sustainability report disclosure of economic dimension positively affects company performance.

\subsection{The Effect of Sustainability Report Disclosure of Environment Dimension on Company Performance}

Disclosure of environment performance becomes a very vital matter to show the existence and participation of the company in dealing with the environmental issue (Nofianto and Agustina, 2014). The participation is a form of company responsibility toward the environment where the company operates. With the 
existence of the responsibility, it will increase the image of the company. As a result, the investor will be interested in investing in the company because the company has a responsibility toward environment meaning that the company has the environmental risk that is relatively low. It is supported by legitimacy theory stating that a company keeps trying in order the activity is run following the norm in the environment.

The study done by Tjahjono (2013) shows that environmental performance positively affects the value of the company through financial performance. The better financial performance, the more increasing company value. Fatchanand Trisnawati (2016) in their study also shows sustainability report disclosure of environment dimension significantly and positively affects company value. It means, with high company value, it reflects that the company has high market value meaning that company performance is valued good by the investor. Based on the above explanation, the hypothesis of the study is:

H2. Sustainability report disclosure of environment dimension positively affects company performance.

\subsection{The Effect of Sustainability Report Disclosure of Social Dimension on Company}

\section{Performance}

Sustainability report disclosure done by the company is expected to be able to give real evidence that production process done by the company is not only for profitoriented goal, but also to pay attention to social issues. By implementing and reporting social responsibility (SO) toward stakeholder, it is not only able to increase the company's average share rate, but also able to increase employee's welfare and loyalty, to decrease employee turnover level, so eventually the productivity of the company is increasing (Ernst \&Young, 2013 in Tarigan and Semuel, 2014).

The more increasing company productivity, the company will affect the increase of employee performance in producing a qualified product that is safe to be consumed by the customer. When customers value the employee's performance good, it will enable the market value of the company to increase, so the company 
performance will be valued good by stakeholder. Eduardus and Juniarti (2016) stated that the dimension of sustainability reporting is a social dimension that has a positive effect on company performance that is proxied with Tobin's Q. The result of the study is in line with the one done by Safitri (2015) that sustainability report disclosure is the social dimension relating positively and significantly toward the market performance of the company. Based on the above explanation, the hypothesis of this study is:

H3. Sustainability report disclosure of social dimension positively affects company performance.

\section{Research Method}

\subsection{Population and Sample}

In this study, the population is all companies listed in Indonesia Stock Exchange in 2014-2015. Sampling will be done using a purposive sampling method with specific criteria which are:

1. Non-financial companies listed in Indonesia Stock Exchange in 2014-2015.

2. Companies that published a sustainability report in 2013-2014.

3. Companies that are studied have a complete annual report for the year 20142015.

4. Companies that give complete data related to a variable of Tobin's $Q$ that is used during the research year.

\subsection{Type and Source of Data}

Type of data in this study is documentary data in the forms of invoices, journals, letters, minutes of the meeting, memos, or in the form of program report. This study uses secondary data obtained from annual reports of companies. Those reports are published in the website of Indonesia Stock Exchange (IDX): www.idx.co.id and the official website of each company. 


\subsection{Operational Definition and Measurement of Variable}

a. Independent Variable

1) Economic Dimension

The dimension of economic sustainability is related to the effect of the organization toward economic condition for its stakeholder and toward an economic system in the levels of local, national and global. The economic dimension consists of 9 items of disclosure.

2) Environment Dimension

The dimension of environmental sustainability is related to the effect of the organization on nature system that is living and non-living, including land, air, water, and ecosystem. Environment dimension consists of 34 item of disclosure.

3) Social Dimension

The dimension of social sustainability discusses the effect owned by the organization on a social system where the organization operates. The social dimension is divided into 4 sub-categories, which are labor practices and work comfort, human rights, community, and responsibility on the product. The social dimension consists of 48 items of disclosure.

To count the disclosure, it uses the calculation of SRDI done by giving score 1 if an item is disclosed and 0 if it is not disclosed. Based on each dimension, it will be calculated by using an index with the formula:

Information:

$$
S D R I=\frac{n}{\mathrm{k}}
$$

SRDI: Sustainability Report Disclosure Index of company

$\mathrm{n}$ : number of items disclosed by the company

$\mathrm{k}$ : number of items expected

b. Dependent Variable

Tobin's $Q$ is the indicator to measure company performance that shows the performance of management in managing company assets. Tobin's Q is used to 
investigate how big market value of the company toward book value of total assets (Muallifin and Priyadi, 2016). If the $\mathrm{q}$ ratio is above one, it shows that the investment in assets produces a profit that gives a higher value than investment expense so that it will stimulate new investment (Herawaty, 2008).

The formula for calculating the ratio of Tobin's Q is (Wibowo dan Faradiza, 2014):

$$
\text { Tobin's } Q=\frac{\mathrm{MVS}+\mathrm{D}}{T A}
$$

Information:

MVS = Market Value of all outstanding shares

$\mathrm{D} \quad=$ Debt

TA $=$ Total Asset

Debt is how much obligation market value, where this value can be calculated using the equation as the following (Wibowo and Faradiza, 2014).

$$
\mathrm{D}=(\mathrm{AVCL}-\mathrm{AVCA})+\mathrm{AVLD}
$$

Information :

AVCL $=$ Accounting Value of the firm's Current Liabilities (Short Term Debt + Taxes Payable).

AVCA =Accounting value of the firm's Current Assets (Cash +Account Receivable + Inventories).

AVLTD =Accounting Value of the firm's Long-Term Debt (Long Term Debt).

\subsection{Data Analysis Method}

a. Descriptive Statistics

Descriptive statistics give illustration or description of data viewed from mean, standard deviation, variant, maximum, minimum, sum, range, kurtosis, and skewness (Ghozali, 2013). 
b. Classic Assumption Tests

1) Normality Test

Normality test aims to examine whether or not the regression model, the independent variable and dependent variable have a normal distribution. There are two ways to detect whether or not the residual normally distribute which are by graph analysis and statistics test (Ghozali, 2013). If the dots pattern spread around the diagonal line and follow the direction of the diagonal line, the data are normally distributed. For statistics test of normality, it uses a One-Sample Kolmogorov-Smirnov Test with a significance level of 0.05 .

\section{2) Multicollinearity Test}

Multicollinearity test aims to examine whether or not in regression model correlation among independent variables is found. Testing of the presence or absence of multicollinearity in the regression model can be done by looking at the tolerance value and Variance Inflation Factor (VIF) value. Cutoff value generally used to show the presence of multicollinearity is tolerance value $\leq 0.10$ or same as VIF value $\geq 10$ (Ghozali, 2013).

\section{3) Heteroscedasticity Test}

This testing is done to investigate whether operated variables have had similar variants (homogeneous). The way to detect the presence or the absence of heteroscedasticity is through plotting graph. The basis analysis is (Ghozali,2013):

1. If there is a specific pattern, such as the existing dots form a specific ordered pattern (wavy, widened then narrowed), it indicates that heteroscedasticity has been occurring.

2. If there is no clear pattern and the dots spread above and under 0 on axis $\mathrm{Y}$, heteroscedasticity does not occur.

\section{4) Autocorrelation Test}

Autocorrelation aims to examine whether or not a linear regression model correlates with a disturbing error in period $t$ and error in period $t-1$ (previously). To 
investigate whether or not autocorrelation occurs in a regression model, this study uses the Durbin Watson Test (DW-Test) with terms $\mathrm{dU} \leq \mathrm{DW} \leq 4$-dU (Ghozali, 2013).

c. Multiple Linear Regression Analysis

Regression analysis used is as the following:

$$
\mathbf{Y} \mathbf{i}, \mathbf{t}=\mathbf{a}+\boldsymbol{\beta} \mathbf{X}_{1} \quad \mathrm{i}, \mathrm{t}-1+\boldsymbol{\beta} \mathbf{X}_{2}+\boldsymbol{\beta}_{\mathrm{i}} \mathbf{X}_{\mathbf{3}} 1 \quad{ }_{3}+\varepsilon \mathrm{i}, \mathrm{t}-1
$$

Information:

$\mathrm{Y}=$ Company Performance (Tobin's $Q$ ) in period $\mathrm{t}$ at company $\mathrm{i}$

$\begin{array}{llll}\mathrm{a} & & & =\text { Constant } \\ \mathrm{X}_{1} & & & =\text { Economic Dimension in period } \mathrm{t}-1 \text { at company } \mathrm{i} \\ \mathrm{X}_{2} & & & =\text { Environment Dimension in period } \mathrm{t}-1 \text { at company } \mathrm{i} \\ \mathrm{X}_{3} & & & =\text { Social Dimension in period } \mathrm{t}-1 \text { at company } \mathrm{i} \\ \mathrm{B}_{\mathrm{B}} \mathrm{B}_{1} & \mathbf{2} & & =\text { Regression Coefficient } \\ \boldsymbol{\varepsilon} & & & =\text { Errorterm } \\ \mathrm{i} & & & =\text { Company }\end{array}$

d. Hypothesis Test

1) Determination Coefficient $\left(R^{2}\right)$

This testing is done aiming to investigate how much the ability of the model in explaining variants of dependent variables. The smaller $\mathrm{R} 2$ value, the more limited ability of independent variables in explaining their dependent variable. This study uses Adjusted R Square (Adj R2) because there are more than one independent variables and if there is only one independent variable, it uses R Square (R2) in explaining the effect of its independent variable(Ghozali, 2013).

2) Simultaneous Significance Test (F Statistics Test)

F-test is used to examine whether all independent or dependent variables included in the regression model have effects simultaneously on the dependent variable (Ghozali, 2013). The criteria of the testing (F-test) are as the following: 
1. Hais rejected if the significance value of $\mathrm{F}>0.05$, meaning that the regression model in this study is not feasible (fit) to be used in the study.

2. Hais accepted if the significance value of $\mathrm{F}<0.05$, meaning that the regression model in this study is feasible (fit) to be used in the study.

3) Individual Parameter Significance Test (T Statistics Test)

This individual parameter significance testing is used to investigate whether independent variable individually affects dependent variable with the assumption that other independent variables are constant (Ghozali, 2013). The criteria of hypothesis testing are as the following:

1. Hais rejected, if the significance value of $t>0.05$ or if significance value is more than the value of $\alpha=5 \%$ meaning that independent variable individually does not affect the dependent variable.

2. Hais accepted if the significance value of $t<0.05$ or if the significant value is less or equal to the value of $\alpha=5 \%$ meaning that independent variable individually affects the dependent variable.

\section{Result and Discussion}

\subsection{The object of Study Illustration}

The population of this study is all companies listed in IDX in 2014-2015. Based on 522 populations, the sample as many as 40 observations are obtained based on the criteria of sampling.

Based on the output of descriptive statistics in Table 1, it can be explained that: 1). Variable of Tobin's Q has to mean of 1.3293325meaning that the average of market value owned by the company is 1.33. The standard deviation for Tobin's $Q$ is 0.76385417. Tobin's $Q$ has the minimum value of 0.04940 and the maximum value of 2.89490, 2). Variable of economic dimension has the minimum value of 0.00000 meaning that as much as $0 \%$ or there is no item from an indicator of economic dimension disclosed by the company. The maximum value of 1.00000 means that the company discloses as much as $100 \%$ or all items from an 
indicator of economic dimension. The mean for the economic dimension is 0.6000000 meaning that the average economic dimension indicator disclosed by the company is $60 \%$ and standard deviation produced is as much as 0.22757096 , and 3). Variable of environment dimension has a minimum value of 0.05882 , meaning that the company discloses $5.88 \%$ items of environment dimension indicators. The maximum value produced is 0.94118 , meaning that the company discloses $94.12 \%$ items of environment dimension indicators. Variable of environment dimension has a mean of 0.3691176 , meaning that the company discloses $36.91 \%$ items of environment dimension indicators and standard deviation produced is 0.24097129 .

Table1.

Descriptive Statistics Result
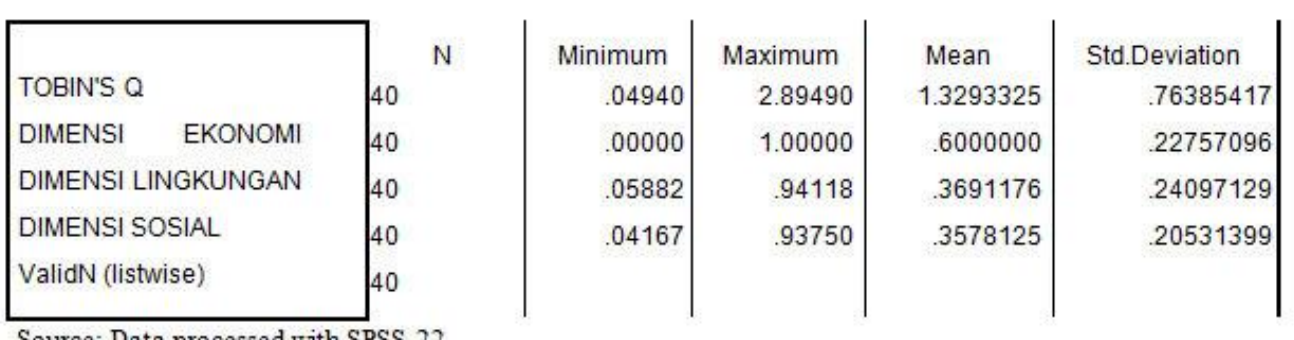

Source: Data processed with SPSS 22

\subsection{Classic Assumption Test}

\section{1) Normality Test}

Normality test in this study uses graph and statistics analysis. Based on the result of the normality test using graph analysis, it shows a pattern of dots scattered around the diagonal line and following the direction of the diagonal line. Based on the result, it can be concluded that the data used in this study are distributed normally. The result of the normality test using statistical analysis of Kolmogorov-Smirnov Z (1Sample K-S) shows the value of Asymp.Sig (2-tailed) of 0.200. It means that the value of Asymp.Sig. (2-tailed) is more than 0.05 or 5\%, meaning that extra data are distributed normally. 
Figure3

Normality Test Result

P Plot GraphKolmogorov-Smirnov (1-Sample K-S)
Table2

Normality Test Result

One-Sample Kolmogorov-Smirnov test

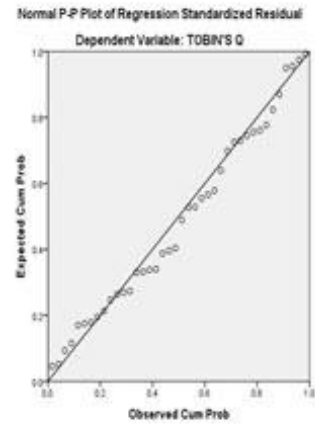

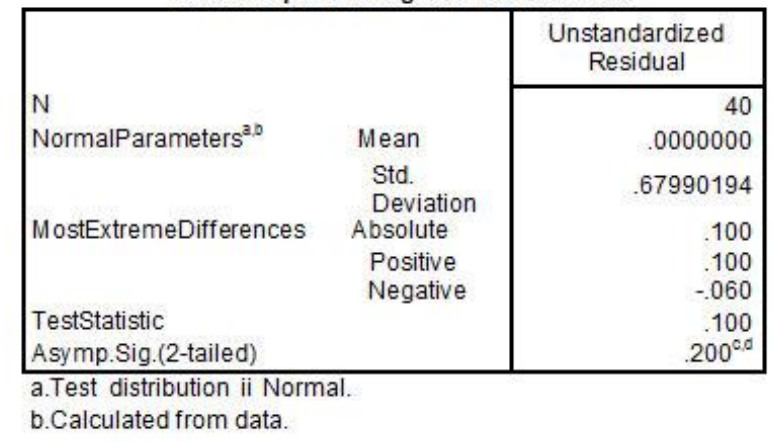

2) Multicollinearity Test

Table 3

Multicollinearity Test Result
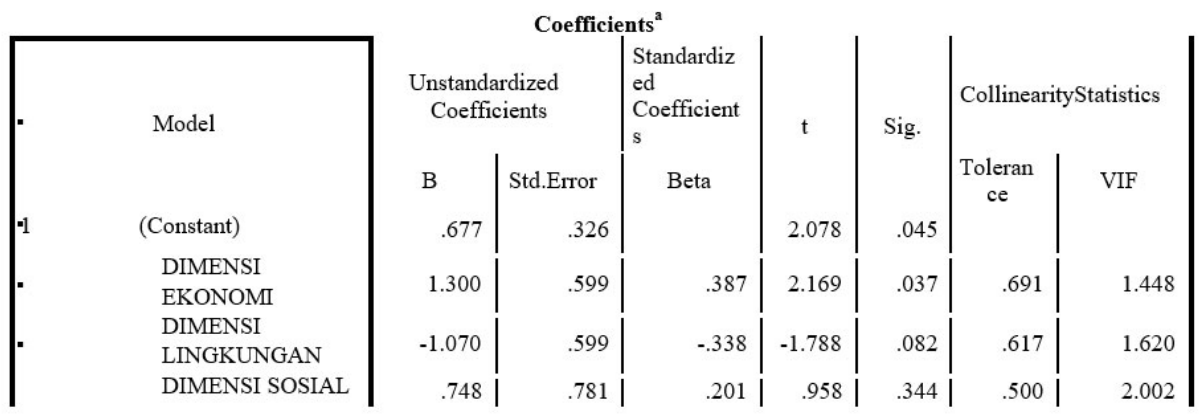

a.Dependent Variable:TOBIN'SQ

Source: Data processed with SPSS 22

Based on the test result in Table 3, economic dimension, environment, and dimension and social dimension, each of them has tolerance value $>0,10$ and the value of $\mathrm{VIF}<10$. Thus, it can be concluded that there is no multicollinearity in the regression model. 
3) Heteroscedasticity Test

Based on scatterplots graph in Figure 4, there are dots spread both above and below 0 on axis $\mathrm{Y}$. Therefore, it can be concluded that heteroscedasticity does not occur in the regression model.

Figure 4

Heteroscedasticity Test Result

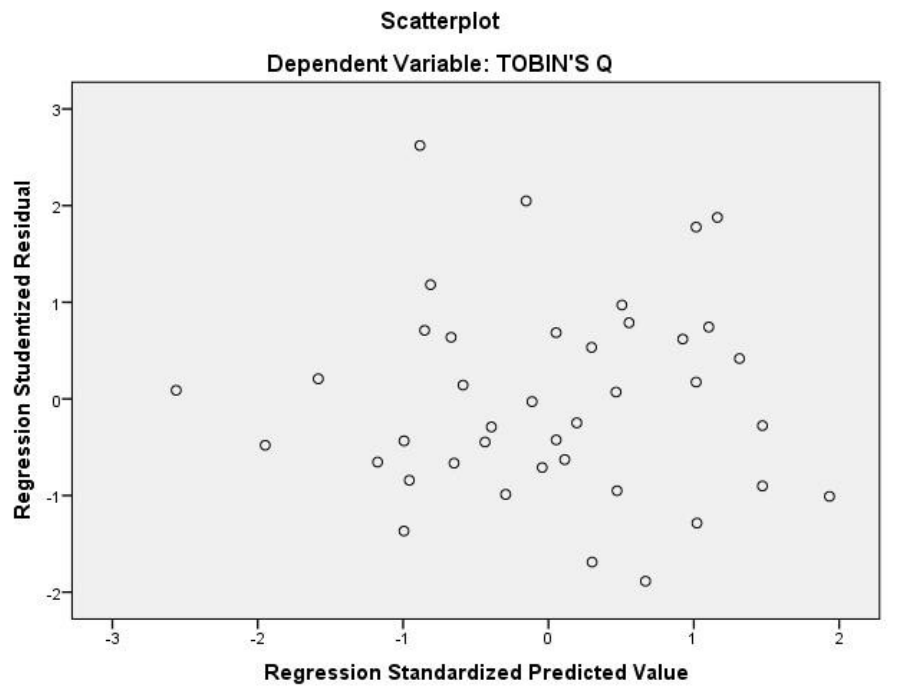

Source: Data processed with SPSS 22

4) Autocorrelation Test

Based on the result of the Durbin Watson test in Table 4, it is known that the value of DW is 2.048 with the above limit (dU) of 1.599. The value of DW is more than the above limit (dU) which is 1.599 and less than (4-dU) 4-1,599 =2,401. Thus, it can be concluded that there is no autocorrelation in the regression model of this study. 
Table 4

Autocorrelation Test Result

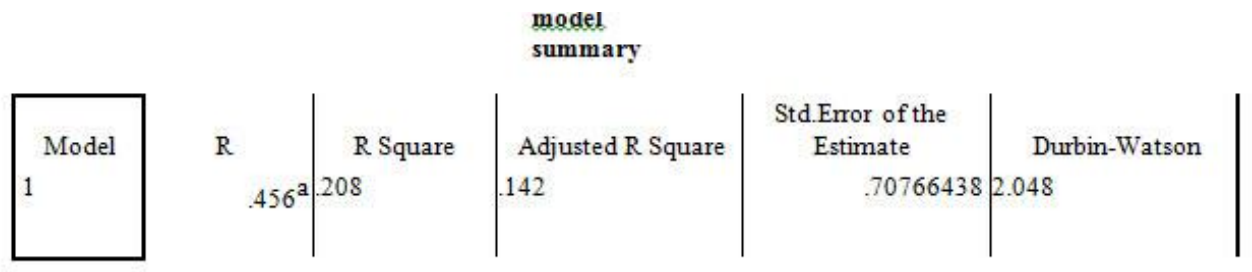

a. Predictors:(Constant),SOCIAL DIMENSION, ECONOMIC DIMENSION, ENVIRONMENT DIMENSION
b. DependentVariable-TOBINS Q

Source: Data processed with SPSS 22

\section{Hypothesis Test}

1) Determination Coefficient

Table 5

Determination Coefficient Test Result (Adjusted $\mathrm{R}^{2}$ )
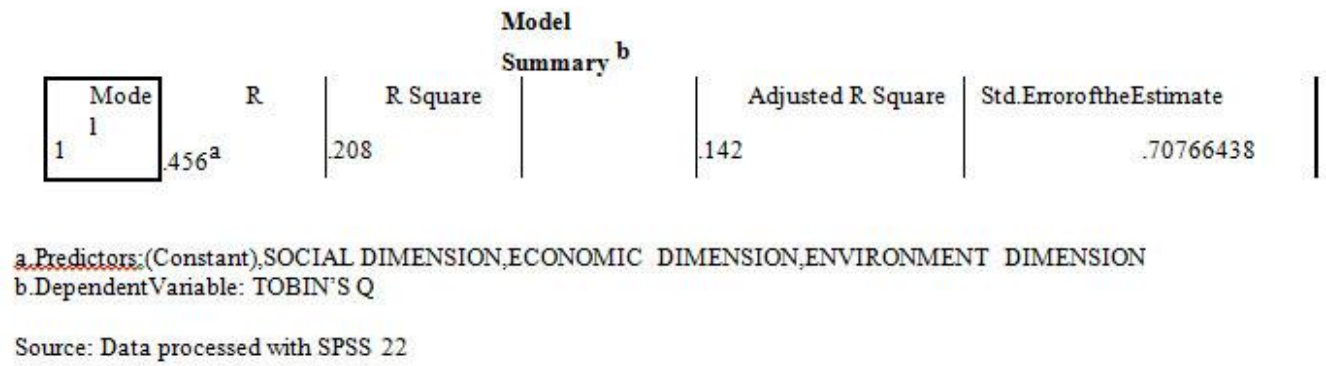

Based on Table 5 above, it is known that adjusted $\mathrm{R}^{2}$ is 0.142 , it means that the ability of independent variable in explaining the variance of a dependent variable is still limited which is $14.2 \%$. There are $85.8 \%$ of other factors that can affect Tobin Q that cannot be explained by the independent variable in this study.

2) Simultaneous Significance Test (F Statistics Test)

Based on Table 6, the result of ANOVA test or F test shows an F value of 3.146 with the significance of 0.037 . The significance value is less than the value of $\alpha$ which 
is $0.037<0.05$ meaning that regression model is feasible to be used to predict Tobin's Q or it can be said that all independent variables (economic dimension, environment dimension, and social dimension) simultaneously affect dependent variable (Tobin’s Q).

\section{3) Individual Parameter Significance Test (t Statistic Test)}

Table 7

\section{t Statistics Test Result}

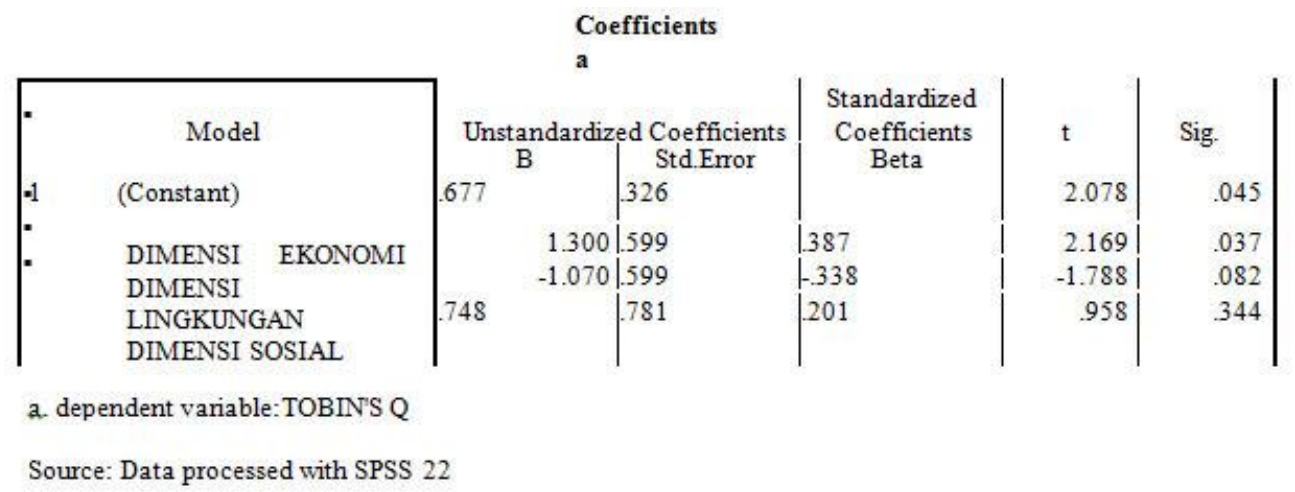

Based on the result of t-test in Table 7, it can be seen the significance level of the effect of the independent variable on the dependent variable individually as the following: 1). Independent variable of economic dimension has $t$ count of 2.169 and $t$ table of 1.688, so t count > t table with a significance of 0.037 (significance value < 0.05) meaning that variable of economic dimension is significant. Therefore, $\mathrm{H}_{1}$ stating that sustainability report disclosure of economic dimension positively affects company performance is stated supported. 2). Independent variable of environment dimension has $\mathrm{t}$ count of -1.788 and $\mathrm{t}$ table of 1.688 , so $\mathrm{t}$ count $<\mathrm{t}$ table with a significance of 0.082 (significance value > 0.05) meaning that variable of environment dimension is not significant. Therefore, $\mathrm{H}_{2}$ stating that sustainability report disclosure of environment dimension positively affects company performance is stated not supported. 3). Independent variable of social dimension has $t$ count of 0.958 and $\mathrm{t}$ table of 1.688 , so $\mathrm{t}$ count $<\mathrm{t}$ table with a significance of 0.344 
(significance value $>0.05$ ), meaning that variable of social dimension is not significant. Therefore, H3stating that sustainability report disclosure of social dimension positively affects company performance is stated not supported.

\subsection{Discussion and Analysis Result}

\subsubsection{The Effect of Sustainability Report Disclosure of Economic Dimension on} Company Performance

Based on the testing result of the variable of the economic dimension of sustainability report toward company performance that is measured with Tobin's Q, it can be known that hypothesis testing result shows that sustainability report disclosure of economic dimension affects company performance, so $\mathrm{H}_{1}$ is supported. The dimension of sustainability report disclosure that is mostly disclosed is economic performance dimension. The more disclosures of economic performance, the better company performance. The information that is disclosed in economic performance will be a consideration for an investor in decision making to invest in the company.

Based on the result of this study, the disclosure of economic performance dimension positively affects company performance. The more disclosures of economic performance dimension, the more increasing company performance. It occurs because the company is more transparent in giving the information needed by investors through economic performance dimension. The transparent information is needed by investors to make an investment decision that will be done. Therefore, when company performance is increasing, then, there will be more investors that will conduct investment in the company. The increase of company performance in this study is reflected on Tobin's $\mathrm{Q}$ value of the company. The increase of Tobin's $\mathrm{Q}$ value shows that investment in assets produces a profit with more significant value than the investment expense.

The result of this study supports the studies done by Safitri (2015) as well as Fatchan and Trisnawati (2016) showing that sustainability report disclosure of economic performance has a positive and significant effect on the value of Tobin's Q. 


\subsubsection{The Effect of Sustainability Report Disclosure of Environment Dimension on Company Performance}

Based on the testing result of the variable of environment dimension from sustainability report toward company performance that is measured with Tobin's Q, it can be known that the result of hypothesis testing shows that sustainability report disclosure of environment dimension does not affect company performance, so $\mathrm{H}_{2}$ is not supported.

The absence of effect between environment performance and financial performance is caused by the habit of investors that less paying attention to what is done by company toward its environment and only paying attention to the condition of company in the market, whether it is profitable or not if investment is made (Astuti, Anisykurlillah, and Murtini, 2014). The profitable or non-profitable condition can be seen from the presence or the absence of additional expense that is spent by the company toward its environment. Therefore, with the presence of additional expense, the profit share that will be received by the investors will be less or having a lower value than investment expense done and it causes the investment in assets of the company less interesting.

The result of this study supports the study done by Astuti, Anisykurlillah, and Murtini (2014) showing that environmental performance does not affect the company's financial performance. However, it does not support the study done by Tjahjono (2013)showing that environment performance positively affects company value (Tobin's Q) through financial performance.

\subsubsection{The Effect of Sustainability Report Disclosure of Social Dimension on Company Performance}

Based on the testing result of the variable of social dimension from sustainability report on company performance that is measured with Tobin's $Q$, it can be known that the result of hypothesis testing shows that sustainability report disclosure of social dimension does not affect company performance, so $\mathrm{H}_{3}$ is not supported. Disclosure of 
social dimension from sustainability report does not affect company performance. Sustainability report disclosure done by the company is expected to be able to give real evidence that production process done by the company is not only for profitoriented goal but also for considering social issues. However, in reality, the attention of the company toward social issues is still low. Most the companies still focus on the company's production that is profit-oriented. Therefore, there are still few companies that conduct social dimension disclosure of sustainability report.

Simbolon and Sueb (2016) explained that the condition in Indonesia, where its disclosure is still voluntary, shows that information disclosure related to social dimension is still the second priority to be considered compared to its economic performance disclosure. It means that companies pay attention more on profit obtained compared to the disclosure related to social issues that have been done. The result of this study supports the study done by Muallifin and Priyadi (2016) finding sustainability report disclosure does not affect market performance that is proxied by using Tobin's Q. However, it does not support the study done by Eduardus and Juniarti (2016) stating that the sustainability report dimension which is social dimension has a positive effect on company performance that is proxied with Tobin's Q.

\section{Conclusion, Limitation and Suggestion}

\subsection{Conclusion}

This study aims to see the effect of sustainability report disclosure viewed from the economic dimension, environment dimension and social dimension on company performance that is proxied with Tobin's Q in 2014-2015. This study uses multiple regression analysis as hypothesis analysis instrument. Based on the result of hypothesis testing, from the three independent variables (economic dimension, environment dimension and social dimension from sustainability report disclosure), it can be concluded as the following: 1). Independent variable of economic dimension positively affects company performance that is measured with Tobin's Q. It shows that the higher disclosure of economic dimension done by the company, the 
better company performance in the next period that is reflected in the company's market value. 2). Independent variable of environment dimension does not affect company performance that is measured with Tobin's Q. It shows that the higher disclosure of environment dimension done by the company will not affect company performance that is reflected in the company's market value. 3). Independent variable of social dimension does not affect company performance that is measured with Tobin's Q. It shows that the higher disclosure of social dimension done by the company will not affect company performance that is reflected in the company's market value.

\subsection{Limitation of Study}

Limitations in this study are as the following: 1). Fewer companies that publish sustainability report because the characteristics of sustainability report that are still voluntary and not every year the companies publish a sustainability report. 2). The observation period is not long, which is only two periods so that the sample used in this study is only a few. 3). This study uses indicator of GRI G4 that might be less suitable, or there is a difference in the condition of the company in Indonesia so that there are only a few companies that disclose new indicators in GRI G4.

\subsection{Suggestion}

Based on the study result above, some suggestions can be given to the researcher for the next study, which are: 1. Paying attention to the criteria of sampling, companies used are not only the companies listed in IDX, for example using SOE companies that have published a sustainability report. 2). Extending the observation period so that the sample used can be more with the expectation to be able to reflect better study result. 3 ). Able to use the newest guidelines that have been adapted with the condition of companies in Indonesia rather than 2013 GRI to measure the disclosure of sustainability report so that the result is more suitable with the condition of the company. 


\section{Reference}

Astuti, FitriaPuji.,IndahAnisykurlillah., dan HennyMurtini. 2014. Pengaruh Kinerja Lingkungan dan Kepemilikan Asing terhadap Kinerja Keuangan. Accounting Analysis Journal, Vol.3, No.4.ISSN 2252-6765. JurusanAkuntansi Fakultas Ekonomi Universitas Negeri Semarang.

Eduardus, Edbert dan Juniarti. 2016. Kinerja Sosial Perusahaan dan Kinerja Keuangan Perusahaan yang Diukur Menggunakan Tobin's q.Business Accounting Review, Vol. 4, No. 1, Januari 2016:517-528.

Elkington, John. 1997. Cannibals with Forks: the triple bottom Linein $21^{\text {st }}$ Century Business. Oxford: Capstone.

Fatchan,Ilham Nuryana dan RinaTrisnawati. 2016. Pengaruh Good Corporate Governance pada Hubungan Antara Sustainability Report dan Nilai Perusahaan (StudiEmpiris Perusahaan Go Public di Indonesia Periode 2014-2015). Riset Akuntansi dan Keuangan Indonesia, Vol. 1, No. 1.

Fiakas, D. 2005. Tobin'sq:Valuing Small Capitalization Companies. Crystal Equity Research. Freeman, R. Edward danJohn McVea. 2001. StrategicManagement: A Stakeholder Approach. SSRN Electronic Journal. Darden Graduate School ofBusiness Administration, University of Virginia.

Ghozali,Imam. 2013. Aplikasi Analisis Multivariate dengan Program SPSS.

Semarang: Badan Penerbit Universitas Diponegoro.

Global Report Initiative (GRI). 2013. Sustainability Reporting Guidelines. www.globalreporting.org.

Herawaty, Vinola. 2008.Peran Praktek Corporate Governance Sebagai Moderating Variable dari Pengaruh Earnings Management terhadap Nilai Perusahaan. Jurnal Akuntansi Dan Keuangan,Vol. 10, No. 2, November2008: 97- 108. Universitas Trisakti,Indonesia.

Indriantoro, Nurdan Bambang Supomo.2014. Metodologi Penelitian Bisnis, Edisi Pertama, Cetakan Keenam.Badan Penerbit Fakultas Ekonomi Universitas Gadjah Mada. Yogyakarta.

Kasmir. 2014. Analisis Laporan Keuangan, Edisi Pertama, Cetakan Ketujuh. Jakarta: Rajawali Pers.ISSN 978-979-769-216-2.

Laan, S. 2009. The Role of Theoryin Explaining Motivation for corporate social Disclosures: Voluntary Disclosures vs. "Solicited" Disclosures. Australasian Accounting Business and Finance Journal, Vol. 3, No 4. University of Sydney.

Maharani, Satia Nur. 2014. Sustainability Reporting sebagai Media Perusahaan dalam Mengembangkan dan Melaporkan Kebijakan Bisnis Berkelanjutan. Modernisasi, Volume 10, Nomor 1, Februari 2014. Fakultas Ekonomi Universitas Negeri Malang. 
Muallifin, Ovi Rizkidan Maswar Patuh Priyadi. 2016. Dampak Pengungkapan Sustainability Report terhadap Kinerja Keuangan dan Kinerja Pasar. Jurnal Ilmu danRiset Akuntansi, Vol. 5, No. 5, Mei 2016.ISSN 2460-0585.

Nofianto, Eko dan Linda Agustina. 2014. Analisis Pengaruh Sustainability Report terhadap Kinerja Keuangan Perusahaan. Accounting Analysis Journal. Jurusan Akuntansi Fakultas Ekonomi Universitas Negeri Semarang.

Nor, Norhasimah Md., Norhabibi Aishah Shaiful Bahari., NorAmiera Adnan., Sheh Muhammad Qamarul Ariffin Sheh Kamal., dan Inaliah Mohd Ali. 2016. The Effects of Environmental Disclosureon Financial Performancein Malaysia. Procedia Economics and Finance 35 (2016): 117-126.

Safitri, Dian Anggraeni. 2015.Sustainability Report erhadap Kinerja Keuangan dan Pasar. Jurnal Ilmu \& Riset Akuntansi, Vol. 4, No. 4. Sekolah Tinggi Ilmu Ekonomi Indonesia (STIESIA) Surabaya.

Simbolon, Junita dan Memed Sueb. 2016. Pengaruh Pengungkapan Sustainability Report terhadap Kinerja Keuangan Perusahaan (Studi Empiris pada Perusahaan Tambangdan Infrastruktur Subsektor Energi yang Terdaftar di BEI Tahun 2010-2014). Paper Simposium Nasional Akuntansi XIX, Lampung 2016.

Sudiyatno, Bambang dan Elen Puspitasari. 2010. Pengaruh Kebijakan Perusahaan terhadap Nilai Perusahaan dengan Kinerja Perusahaan sebagai Variabel Intervening (Studi pada Perusahaan Manufaktur di Bursa Efek Indonesia). Dinamika Keuangan dan Perbankan, Vol. 2, No.1, Mei 2010: 1-22.ISSN 1979-4878.

Sustainability Reporting Award. SRA.NCSR-ID.ORG. diakses 28 September 2016. http://sra.ncsr-id.org/sra-participant/.

Tarigan, Josuadan Hatane Semuel. 2014. Pengungkapan Sustainability Report dan Kinerja Keuangan.Jurnal Akuntansi dan Keuangan, Vol. 16, No. 2, November 2014:88-101. SSN 1411-0288 print/ ISSN 2338-8137 online.

Tjahjono, MazdaEko Sri. 2013. Pengaruh Kinerja Lingkungan terhadap Nilai Perusahaan dan Kinerja Keuangan. Jurnal Ekonomi, Vol. 4 No. 1, Mei 2013.

Wahyuni, Ersa Tri. 2015. Tag Archives: Sustainability report. 16 Maret 2015 diakses 27

Nopember 2016. http://etw-accountant.com/tag/sustainability-report/

Wibowo, Imam dan Sekar Akrom Faradiza. 2014. Dampak Pengungkapan Sustainability Report terhadap Kinerja Keuangan dan Kinerja Pasar Perusahaan. Simposium Nasional Akuntansi XVII Mataram, Lombok. 
Wijayanti, Rita.2016. Pengaruh Pengungkapan Sustainability Report terhadap

Kinerja Keuangan Perusahaan. Syariah Paper Accounting (Menakar Peran Profesi sebagai Engineof Reform dalam Pembangunan Global Berkelanjutan). Fakultas Ekonomi dan Bisnis, Universitas Muhammadiyah Surakarta. ISSN 2460-0784.

Wiwoho, Laksono Hari. 10 Tahun Lumpur Lapindo, Bencana dan Keberuntungan. WWW.KOMPAS.COM.15 Juni 2016 diakses 27 Nopember 2016. http://regional.kompas.com/read/2016/06/15/15382461/10.tahun.lumpur.lapindo.benca na.dan.keberuntungan?pag 
The Indonesian Journal of Accounting Research - Sep, Vol. 20, No.3, 2017

intentionally blank 